\title{
Safe Haven Currencies
}

\section{Vessela Todorova*}

\section{Summary}

As other safe haven assets, safe haven currencies are sought by investors to mitigate financial risk when economic turbulence hits. Three major safe haven currencies are the US dollar (USD), the Japanese yen (JPY) and the Swiss franc (CHF). The euro is now in competition as an alternative safe haven currency. US dollar will remain the best safe haven currency in the short term and the best investment currency in the medium term. In every uncertainty of the US equity market as well as in the case of a decline of the US dollar, the investor may consider investing in a safe haven currency like the yen or the Swiss franc. Given the stability of Swiss government and financial system of the country, the increased foreign demand for the currency usually pushes the Swiss franc upward. There are number of factors, characterizing the dynamics in which the investors fall, rushing to the Japanese yen during periods of global risk aversion. Traders looked for refuge in the cryptocurrency because they cannot find refuge elsewhere.

Keywords: Safe Haven (s), Safe Haven asset, Safe Haven Currencies, Information Insentivity, Convenience Yield, Risk Aversion, Risk Spectrum, Safety Trap.

JEL: E4, E5, E6, F1, F3, F4, G1, G2, G3

\section{Introduction}

The academic and policy interest in safe assets is rising. The phenomenon "Safe Haven" is generally regarded as an investment that markets hope to retain or increase in value during turbulent times. All stores of value come in many forms cash, bank deposits, government Treasury bills, corporate bonds, stocks, repurchase agreement, derivatives, real assets such as real estate, land, gold and others. They differ in their degree of liquidity - the ease with which they can be traded - and their sensitivity to various risk factors (Caballero and Farhi, 2017).

The narrow pragmatic definition includes the accents of Dang, Gorton and Holmstrom (2015) and Gorton (2017) on "information insensitivity", in the sense that safe assets are relatively immune to the costly production of private information about their value or can be transacted without much analysis or concerns for adverse selection (Caballero, Farhi and Gourinchas, 2017). It is also consistent with Caballero and Simsek's (2013) view that "simple" assets have special value during economic crises that are inherently complex and that an asset is safe if others expect it to be safe (Farhi and Maggiori, 2016), (He, Krishnamurthy and Milbradt 2016).

Safe assets play a special, fundamental role in the economy, determined by the existence of nonpecuniary returns (called the "convenience yield") in the form of liquidity

\footnotetext{
* UNWE, Faculty of International Business and Politics
} 


\section{Articles}

or moneyness and safety. Currencies, in whatever forms, U.S. Treasuries, privatelyproduced substitutes, ABS/MBS, all provide a convenience yield. The empirical models are also not so many and mainly involve investing the US liabilities, especially the theory of the "convenience yield" (Krishnamurthy and Vissing-Jorgensen, 2012). The liquidity and safety attributes of US Treasuries are of great importance for the investors whose equilibrium price is driven and determined by changes in their supply. One exception to the strict focus on U.S. liabilities is Du et al. (2018), who measure the difference in the convenience yield between the latter and those in other developed countries.

The literature on the characteristics of the safe assets is limited regardless of the need for such research. He et al. (2016) underline the synchronization among investors as a safeness driving force in theory. The big size of the absolute debt in their model is vital for safe-asset investors and the effect gets stronger in turbulent times. There has always been a demand for safe assets and a lack of safe assets constrains transactions and consumption smoothing. Sovereign debt is not always safe and can provoke sovereign debt crises. Under shortage of publicly-produced safe assets, the private sector produces substitutes. That is the source of systemic fragility.

The investors are seeking safe assets to limit their losses mainly in the event of downturn tendencies (Gorton, 2017; Gourinchas and Jeanne, 2012). They are aiming to diversify their portfolios by using a safe haven investment in times of market volatility. Usually for a short period of time, the markets rise or fall. Yet it is possible that the market downturn be prolonged during an economic recession. When the markets are in turmoil, the market value of most investments falls rapidly and steeply. In other words, in systemic times of market distress, investors seek to buy safe haven assets that are uncorrelated or negatively correlated to the market conditions. Safe haven assets either retain or increase in value, while most assets are falling.

The necessity of safe assets has risen since the global financial crisis of 2007-2008 with important aftermaths (Caballero et al., 2017). For such assets, the "equilibrium" safe real interest rate declines in the presence of excess demand below zero and below the actual rate, as nominal rates hit the zero lower bound and central banks are not able to decrease real rates. In such cases, the appreciation of the currency of issuance of the safe asset is an adjustment mechanism, known as "paradox of the reserve currency" (Habib and Stracca, 2012). But "a safety trap" equilibrium appears when prices and exchange rates fail to clear the market of safe assets by shrinking the demand (Caballero et al., 2016).

The global financial crisis has renewed public attention on safe haven currencies. There is a remarkable disproportion between media coverage and financial market literature on safe haven currencies. The media interpretation is highly changeable and contradictory in comparison with the scientific literature. A currency considered safe at one point in time may not be considered safe just few months later. On 30 August 2002, the Straits Times published the title "(The) Greenback still a safe haven currency" and three months later the International Herald Tribune wrote "U.S. dollar loses its appeal as world's "safe haven" currency" (Ronaldo and Soderlind, 2007). The paper addresses the question what are the possible safe haven currencies for investors to mitigate financial risk when economic turbulence hits. The three major safe haven currencies (and their related safe haven investments) are U.S. dollar (USD) 


\section{Articles}

and U.S. Treasuries, the Japanese yen (JPY) and Japan's government bonds and the Swiss franc (CHF) and Swiss government bonds.

There are studies, such as those conducted by Habib and Stracca (2012), which have tried to determine the characteristics of safe haven currencies. Only a few factors are strongly connected with safe haven status, most notably: the net foreign asset position - an indicator of external vulnerability and of market size and development; the interest rate spread against the USD, only for the advanced countries, whose currencies are subject to carry trade and it is hard to predict what the currency would do when the global risk aversion is high.

Ronaldo and Soderlind (2009) documented that the JPY and the CHF, as well as the euro (EUR) and British pound (GBP), may be determined as safe havens during crisis. The 2008 financial crisis can be taken as an important case study that exposes specific factors may have been at play during the crisis. McCauley and McGuire (2009) highlight the role of USD shortages - which were generated by the funding of long net USD exposure by Europeans banks - and the role of "overhedged" USD positions - resulting from write-downs of USD assets - supporting the USD exchange rate during the latest crisis. Hui et al. (2010) prove econometrically the influence of market-wide liquidity risk on exchange rate movements. On the other hand, Fratzscher (2009) has done a more traditional "fundamental analysis", finding that countries with low foreign exchange reserves, weak current account positions and high direct financial exposure vis-à-vis the United States depreciated the most during the crisis. But the analysis is limited to the 2007-2009 financial crises.

\section{Safe haven Currencies}

In turbulent and volatile times with various features, all participants of the market - investors and carry traders - tend to seek currencies for protection, considered as safe havens, to convert their cash holdings into them and to maintain value. The value of the refuge currencies is rising, even though the events might not have had a considerable impact on the currency in question. It means that the liquidity of all these currencies could be a driver of safe haven standing. These are the currencies from the major currency pairs with larger liquidity than exotic currency pairs.

Once the risk aversion is high, liquidity in the markets could dry up. The traders are inflicted to speculate in extremely liquid currencies. In turn, this offers the foremost liquid currencies an additional rising. In case of safe and low risk and international crisis isolation, smart fundamentals of a country, like economic policy and powerful trade, ought to be the safe haven driving force. In theory, the currencies of such countries may well be seen as refuge currencies. Or the status of safe-haven currencies is traditionally linked to a country that has large current account surplus, low sovereign risks, and/or its high share in trade settlements.

The determinants of safe-haven currencies based on the economic fundamentals may have been changed by the financial crisis, as the 2008-2009 financial crises. The crossasset correlations rose broadly in the financial crisis, as a result of the interdependence between the central banks in the world and the sentiment of the investor risk. The cross-asset co-movement and higher policy uncertainty stimulates the exchange rate movements.

High-interest rates currencies are unlikely to be safe-havens, as interest rates are often correlated with high inflation. Carry traders usually borrow in low-interest rate currencies to buy high-interest rate currencies during risk-on periods, during risk-off periods they exit out of the high-interest rate currency (likely a more risky currency) and buy back 


\section{Articles}

the low-rate safe-haven currency. The lowinterest rate in the country is the one thing in common of the JPY, the CHF and the EUR, acting as safe-haven currencies.

The current account balance is another factor. Countries with a large deficit are more likely to depreciate in value in comparison with those with higher export compared to import.

Yet in the increasingly globalized world factors just like the size of a country's stock exchange, which indicates the development of the money and capital markets, outweigh the external vulnerability related to its internet foreign position. The large positive ratio of net foreign asset position and the reserves means it is likely that the country has some issues with debt service payments or experiences liquidity problems.

Whenever there is what is called "risk aversion", investors tend to place their money into the safe haven currencies. The opposite to "risk aversion" - "risk appetite" describes those investors who invest in higher-risk currencies. In risk aversion, the markets are considered to be too volatile and that even relatively safe risks are no longer safe. Investments are made into safe haven currencies. The CHF and the JPY are the most prominent ones. In times of increased global risk aversion, these are the only currencies that appreciate against all other currencies, including the USD. This can often have the effect of even further reducing the value of higher risk currencies.

The JPY typically appreciates in higher volatility of the financial markets. The JPY had been rising since 2010 despite the debt and trade deficits of Japan's government. The trend - clearly proved by the referendum result of the UK EU membership of 23 June 2016 - has been solidified since the mid of 2015 (Masujima, 2016). The widening yield differentials between the United States and Japan are a prerequisite for the weakening of the JPY. The currency is vulnerable to sudden gains on higher risk aversion. On the other hand the Swiss monetary authorities have suffered from its currency's safe-haven status. The central bank's board member Andrea Maechler said on 5 April 2018," The pressure on the Swiss franc is still there, the currency has devalued and the overvaluation has reduced, but the franc is still a safe haven." (Masujima, 2019).

It is possible that the safe-haven status signals in advance changes in the risk appetite in the foreign exchange market. Higher volatility in the U.S. stocks could affect the expectations about the future monetary policy of major central banks. That may result in shifts of capital out of USD and into the JPY. The Brexit shock and the delay in the Federal Reserve's rate increase led to JPY appreciation due to higher safe-haven demand and narrowing government bond yield differential between the United States and Japan. So safe-haven status provokes changes in exchange rates.

Low interest rates, higher liquidity and current account surplus are the common factors determining the safe-haven status of the JPY and the CHF. The safe-haven behavior of the currency exchange rate changes causes restrictions of export in times of crisis. Therefore tracking a currency safehaven status and exploring its determinants help the economic and financial market policy of the financial authorities, investors and corporations.

The political uncertainty recently starting from the U.S. protectionism on world trade to Federal Reserve's interest rate policy and the political events in Europe could affect negatively the JPY, the CHF, the currencies of commodity exporters and emerging markets, while push the demand for alternative safe-haven assets such as gold and cryptocurrencies. 


\section{Articles}

\subsection{The USD: a "natural-born" safe- haven asset.}

The USD has always been the currency to turn to in times of uncertainty that could be relied upon to maintain its value. In periods of uncertainty with respect to currency fluctuations, particularly during periods of trouble when confidence in high yielding currencies was poor and a safe currency haven was being sought, the USD was first line as a safe currency for investment. The sufficient liquidity and the leading role as a key reserve currency determine the USD a reference currency in which investors put their money if the risk suddenly rises up. The USD has been regarded as a safe haven currency for many years, and has been the investment currency of choice during turbulent periods in world history.

During the second half of the 1990s there was a continual increase in the global Forex reserves from $59 \%$ to $70.9 \%$ of the global total currency reserves, an overall increase of
$20.2 \%$. The German mark (DM) was the only truly competing currency during the pre-euro time.

In more detail, the Bank for International Settlements (Triennial Central Bank Survey, 2019) latest triannual survey of the FX market shows that, in April 2019, $88.3 \%$ of total daily turnover involved the USD, 32.3\% the EUR, $16.8 \%$ the JPY and $5 \%$ the CHF. IMF data on the currency composition of official foreign reserves also shows that, at the beginning of 2018 , the USD made up nearly $62 \%$ of global allocated reserves, as opposed to $20 \%$ held in EUR, nearly 5\% in JPY and a negligible $0.2 \%$ in CHF. Out of the 192 counties that registered its exchange rate regime at IMF, the USD is the exchange rate anchor for 38 of them. Nearly two-thirds of all debt globally is denominated in USD or USD-pegged currencies. This explains why in times of debt crises, the USD gets stronger as other currencies and assets are sold to buy dollars in order to pay debts.

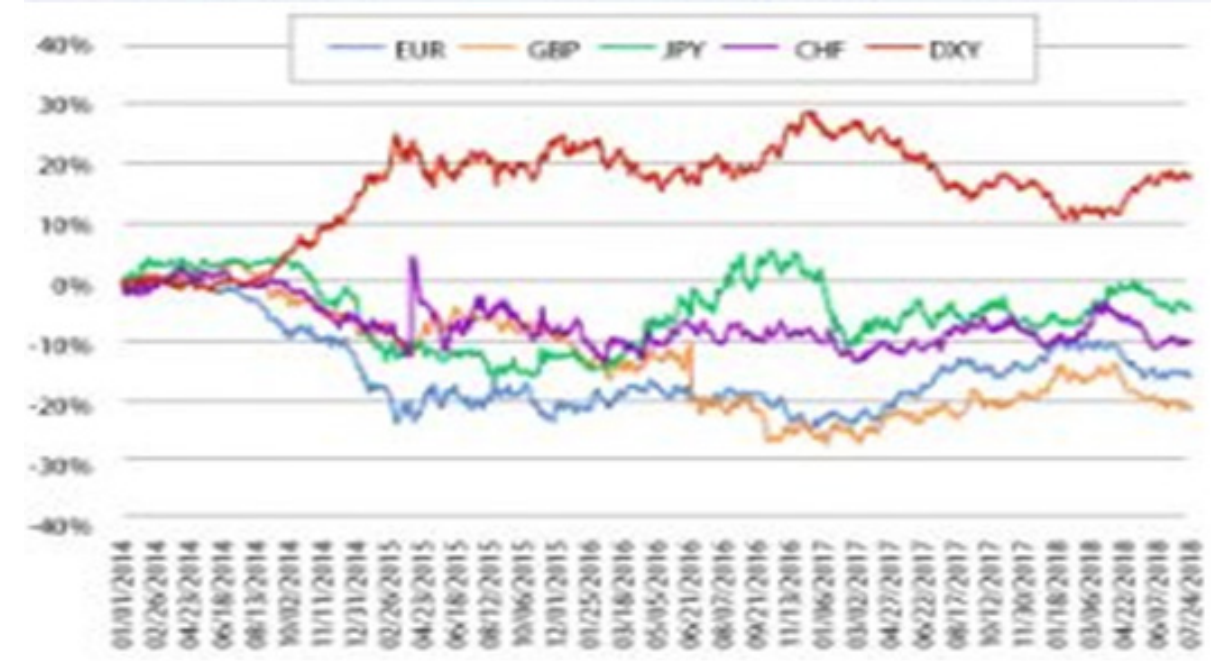

Figure 2-1: EUR, GBP, JPY, CHF and DXY changes against USD /January 2014 - July 2018/

Source: www.tradingeconomics.com

\footnotetext{
${ }^{1}$ See http://data.imf.org.
} 


\section{Articles}

Since 2014, the USD has risen $16 \%$ against the EUR, 21\% against the GBP, 10\% against the CHF and 5\% against the JPY. Overall, the USD Index, which is an index of the USD versus the other major currencies of the world, is up 18\% from January 2014 to July 2018.

In 2017, the financial press was predicting the future weakening of the USD throughout 2018 as a result of the outcome of the US election and rising growth expectations around the world. At the beginning of 2018, the trend changed and the USD began rising.

Economists believe that the USD is in the early stages of a major rally, which should bring the USD at or close to the highs it achieved in 1985. The USD's rise from 2014 to today can be compared with the previous rallies from 1981-85 and from 1995-2002. During periods of weak USD, the global economic conditions were very positive and political conditions around the world were stable. In other words, if the global economic conditions are improving and the geopolitical climate is stable, the USD can be expected to weaken; or else, if the economic conditions are deteriorating along with rising geopolitical tensions, then it can be expected to get stronger.

The USD is already performing well as a safe haven currency during this time of rising geopolitical tensions and falling economic growth expectations. In addition, contrary to common belief, trade wars, debt crises and lower oil prices result in a stronger USD not a weaker USD.

Global emerging market equities have historically had a mixed relationship with the USD, which makes the future uncertain. The hiking rates of the Federal Reserve and all tax reforms in the United States have a positive impact on the USD. Nevertheless the currency began to decrease since December 2017. The weak USD is positive for the exported commodity prices, denominated in US currency. The liquidity in the financial markets is also rising, mainly in the emerging markets. A company with high amounts of USD-denominated debt but little dollar earnings will be influenced by the rising USD; conversely it could benefit from its decline as the debt costs go down.

From the historical point of view, according to Edward Evans, portfolio manager at Ashmore $^{2}$ UK, emerging equity markets have suffered from downfalls during periods of strong USD, so investors are becoming more cautious. Currently Turkey is most at risk to a strong USD. Its current account deficit is $5 \%$ of GDP and financed by short-term trade flows. Edward Evans (https://www.ipe.com , reports , 10023453.article) says: "If global liquidity dries up, this would cause a big headache for Turkey. The current political environment is not helpful either". Argentina is another country that faces the global liquidity risk as its current-account deficit is around $4 \%$ of GDP.

Emerging markets investors believe in longterm convergence between the emerging and developed economies. James Wood-Collins ${ }^{3}$, CEO of Record Currency Management, will generate returns for holders of emerging market currencies, either through appreciation or interest rate. Developed markets are moving at a similar pace, albeit with different economic cycles.

It is considered that emerging markets are playing catch-up. That is the reason for the different long term behavior. "In the long run,

\footnotetext{
2 Ashmore Group is a British specialist Emerging Markets investment manager with over twenty-five years' experience in these markets.

${ }^{3}$ In 1983 Neil Record founded Record Currency Management - one of the world's largest and longest standing independent currency managers where he has been principal shareholder.
} 


\section{Articles}

as a sterling or EUR investor, you don't expect to make money by holding USD or JPY, but you do expect to get additional volatility going through currency cycles. Managing that unrewarded risk through hedging programs is a big part of what we discuss with clients," says Wood-Collins. (https://www.ipe.com , reports , 10023453.article)

Wood-Collins' statement is in contrast with the emerging markets' (EM) philosophy, where the convergence process would push developed market investors to make money through currency exposure. He claims that two consequences explain the profit from the emerging currency risk. First, hedging emerging market risk is a result of strategic rather than tactical interest. Few of Record's clients have searched for hedging emerging currency risk as their expectations to make a profit are based on such currency exposure. Second, there is a case to invest in portfolios that are long EM currencies and short developed market currencies completely detached from other EM assets.

Record's fund of emerging market currencies included 12 currencies 10 years ago and has slowly raised to and over 20 . The confidence that the country is on a convergence route is the most important criterion for emerging market currencies. Productivity calculated on per-capita GDP is the engine for price-level convergence. The result can be domestic inflation which would be fatal without an appropriate monetary and interest rate policy. Therefore monetary discipline is the second criterion for stopping the devaluation of returns. The third criterion is capital market liquidity and tradability.

"Given the frothiness in global high yield, one could even see emerging market debt as a relative safe haven," ends Kos. (https:// www.ipe.com > reports $>10023453$.article) The USD weakness is determined by the investors as a short-term tactical play and a long-term structural one.

To determine the role of the USD as a safe-haven currency, we have to compare it with other critical assets, like gold and stock prices and to make an assessment in the context of the current trade rows.

\subsection{The EUR: "between strength and weakness".}

The EUR is now in competition as an alternative safe haven currency. Many argue against it due the diversity of the nations involved in "euroland": from the strength of German and French economies to the weakness of the eastern Europeans, and smaller exporting countries such as Greece and Portugal. It didnot help the economic and political processes in the UK.

The points in favor of the EUR include its ability to remain stable in spite of fluctuating interest rates between member countries. The stability of the common currency, accepted by so many diverse countries, guarantees the import and export between the member states without the exchange rate affecting budgets. This in turn leads to stability of interest rates, control over inflation and a more stable common currency.

The EUR certainly appears to have maintained that stability in practice. From $17.9 \%$ of the total global EUR exchange reserves in 1999 continuous growth over ten years to $26 \%$ follows in 2010 . Then the reserves in the common currency fell to $22.6 \%$ in 2014 and remained still the last three years (2017-2019). ${ }^{4}$

\subsection{The CHF: back as a safe haven.}

The CHF is also considered to be a safe haven currency. It has always been used as a relatively secure currency, but in this case because of inflation in Switzerland, a country

${ }^{4}$ data.imf.org , COFER 


\section{Articles}

that has stood aloof from its European neighbors and has invariably retained neutrality in war and not part of the EU. There was also at one time a legal requirement for CHF to be backed up by a minimum $40 \%$ of gold reserves, which also added to the security of the currency as a safe currency.

The CHF goes back a long way, predating the foundation of the Swiss National Bank (SNB). The currency, considered the researchers, is an integral part of national identity of the country. More than just a legal tender, the Swiss currency has played an important part in making Switzerland the country it is today.

The CHF was introduced to the Swiss Confederation in 1845. The aim was to make trading easier and facilitate the spread of the currency. It took 20 years for the CHF to reach parity with French franc (FRF), which happened after the currency joined the Latin Monetary Union. Following that, the CHF went from strength to strength. Eventually it has been seen by investors as a safe haven.

In the early 1920s, the CHF began to build solid foundation that would eventually lead to the safe haven status it enjoys today. In Germany at that time the deutsche mark declined in value because of hyperinflation problems. The CHF survived because it kept to the gold standard. This made it very attractive to the investors and made it one of the most expensive currencies in the world. Unfortunately, this had a negative effect on exports. Consequently, Switzerland suffered an increase in unemployment in the 1930s.

The Second World War increased the trade with Germany and vast amounts of gold were deposited in Swiss banks. After the war, Switzerland refused to sign up to the Bretton Woods agreement, which was based on the idea of pegging currencies to the USD. This turned out to be a wise choice as the system collapsed in 1971. As a result the CHF strengthened due to market supply and demand of the currencies. It was then that the freely floating exchange rate regime among the currencies was adopted. The other currencies were therefore priced in relation to Swiss currency. This naturally attracted investors from all over the world, although it was a difficult time for the local industry and Switzerland was once more hit by rising unemployment.

The oil crisis was the other challenge in the 1970s. SNB could not prevent the CHF from sky-rocketing. Tougher times set in during the late 1980s. The worldwide stock market crash burst the real estate bubble. Switzerland fell into a major recession. Despite the difficulties, the CHF has stood the test of time and is still going strong.

The CHF virtually remained strong against all currencies despite the many crises in the world economy. The subprime mortgage crisis that devastated the US banks is the most recent example. The SNB responded by dropping its exchange rates to zero in order to protect the national banking system. Capping the CHF against the euro helped to save Switzerland's export. As a result the franc flooded the markets and was yet again seen as a safe haven.

\section{Features of the CHF as a safe haven currency}

The first reason is the strong and steady economy of the country. Switzerland has always managed to maintain stability despite the many crises that hit the world's financial markets. By staying outside of the EU, the country is acting as a barrier against any political and economic influence of the region. The country's relatively low level of national debt is another important feature. Most of the world's top 10 economies have debt ratios of around $100 \%$ (or sometimes more). Switzerland's is less than $30 \%$. 


\section{Articles}

Like all countries with a strong currency, Switzerland is very attractive for foreign investors, which in turn makes its currency even more valuable. In 2016 the SNB allowed the $\mathrm{CHF}$ to fall slightly against the USD and the JPY. Before that year Switzerland brought heavily into the euro in order to maintain the artificial ceiling. The policy of the ECB (European Central Bank) at that time was to buy debt and inject liquidity into the markets. This made it very hard for the SNB to maintain its rates and maintain a safe-haven currency. So in order to keep a strong franc for imports and increase buying power, it removed the cap.

It is sometimes very difficult for the Swiss industry to cope with the strength of the CHF. The strategy as a whole has been successful. In medium term the success was achieved in all areas of the national economy. That's why Switzerland's currency is of such political and economic importance. In other words, the national prosperity depends to a large extent on the safe haven that the CHF is.

\subsection{The JPY: always a safe haven.}

The JPY's role as a safe-haven currency has been well documented. As economists said, the JPY's strength is simply not a function of domestic economic performance (Mattew, 2016). As illogical as that may sound, this is the case in reality.

The JPY is often considered the top haven in FX markets, with the CHF often not far behind. During risk-off times these are the two currencies that are appreciating relative to the USD. Japan is famous with negative interest rates, positive current account balance; the world's largest creditor; the country with the highest positive ratio of net foreign asset position and the reserves, followed by China for 23 years in a row. During times of uncertainty, such as the Brexit vote, investors tend to orient to the JPY. This causes the JPY to appreciate and has led to the common perception of the yen as a safe-haven currency.

Normally the JPY is strengthening during periods of risk aversion. That is why the global investors are orienting to the currency of the world's most indebted nation whenever trouble arises. During the financial crisis and its aftermath, the yen appreciated by more than $20 \%$. Later in 2010, problems around the peripheral European debt countries - Greece, Spain, Ireland, Portugal, and Cyprus led to a 10\% appreciation against the EUR. That happened again in 2013 amid the political uncertainty surrounding Italian elections when the Japan currency rose over $5 \%$ against the EUR and $4 \%$ against the USD in a single day. Even when Japan is leveled by the Great East Japan earthquake in 2011, the currency managed to rise.

\section{Features of the JPY as a safe haven} currency

The status of the JPY as a safe-haven currency is driven partly by Japan's record debt levels. In terms of debt-to-GDP, they are so far ahead that it is difficult to see them. The government is doing everything in their power to battle the deflation. The interest rate are so low, nearly $2 / 3$ of the country's debt trades at negative yields.

Japan has always been a large exporter and has permanently exported large amounts of goods and services than it imported. Decades in a row the registered current account surpluses positioned the country as a net creditor to the world. This characteristic is also typical of the Swiss franc, as mentioned above.

The value of foreign assets held by Japanese investors is substantially higher than the value of Japanese assets owned by foreign investors. For the 28th straight year, 


\section{Articles}

Japan's net assets overseas are larger than any other nation. ${ }^{5}$ For the end of 2018 , the net international investment position was JPY 341.556 trillion (USD 3.1 trillion), an increase of JPY 12.254 trillion, or 3.7 percent, over 2017. For comparison, at the end of 2015 it is JPY 339 trillion, based on data from Finance Ministry. At the end of 2018, overseas assets held by Japanese banks reached JPY $1,018.038$ trillion, an increase of 0.5 percent from the end of 2017. It marked the seventh straight year for record overseas assets. (SHIKI IWASAWA, 2019)

The interpretation of behavioral theory is simple: when markets become risk-averse, the money is returning back home. The repatriation of capital happens at the same time with the outflow from other currencies and inflow into the JPY, causing it to rise in price.

To some extent it is strange that the most indebted nation in the world (based on the debt-to-GDP) is also the largest creditor in the world. This is due to the fact that greater part of Japan's debt is held almost entirely by the Japanese public. As the press said, "The Japanese government is in deep debt, but the rest of Japan has ample money to spare."(Tabuchi Hiroko,2011)

Japan has also been in the first place in terms of low-interest rates. Japan has held the interest rates at record low levels in its attempt to fight deflation and stimulate economic growth for nearly 20 years. The chart below shows that Japan's discount rates have been at or near zero for the last two decades.

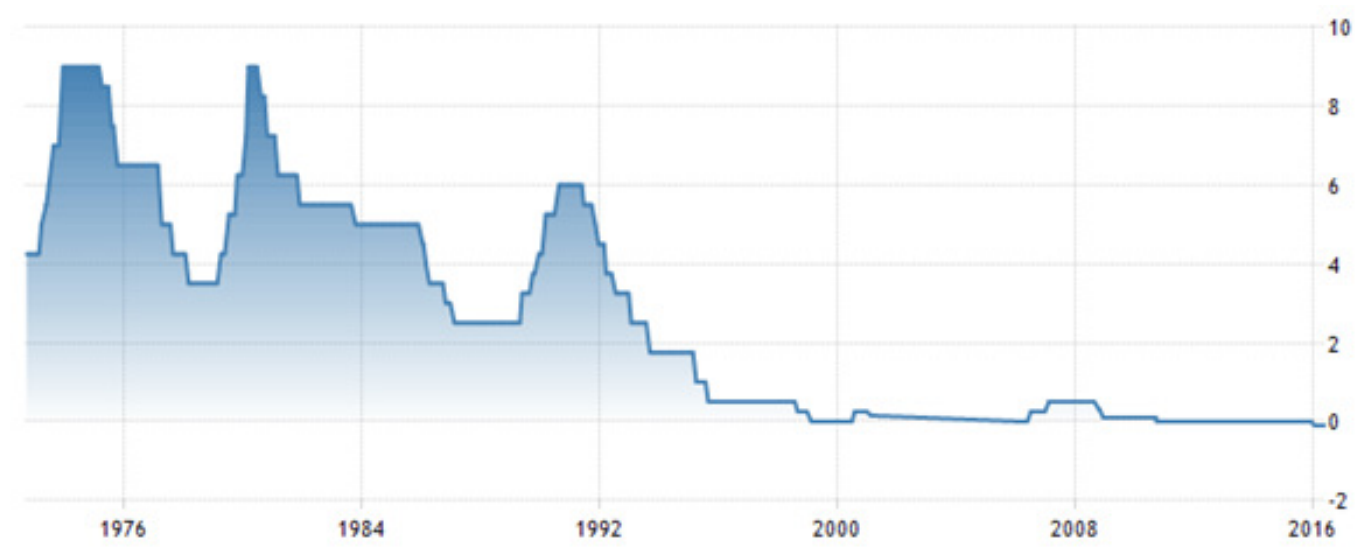

Figure 2-2: Interest Rate Changes in Japan from 1979 to 2016

Source: www.tradingeconomics.com /bank of Japan/

In a low-interest rate environment, investors tend to borrow money and then invest in higher yielding assets from other countries. The greater uncertainty in the global markets can push investors to act in the opposite direction to further increase the demand for the JPY. Very often they are taught to ignore the fundamentals and to follow only the fluctuations. It is the same as ignoring the causes and effects of all repetitive chart patterns or certain relations instead of looking for making profits from them. These are some of the reasons why the JPY is going on to act as a safe-haven currency because all market participants recognized it as such.

\footnotetext{
5 The position is calculated by subtracting the value of assets in Japan held by foreigners from the amount abroad owned by the Japanese government, companies and individuals.
} 


\section{Articles}

\section{Safe haven Future}

The global economy today is experiencing one of the longest expansion periods. Since the 2008 global financial crisis, the economy has enjoyed nearly a decade of growth. The worse-off start of the 2008 global financial crisis in comparison with the Great Depression of 1929-1938 is a case in point. The recovery started somewhere in July 2009. The last July of 2019 marked a decade since the world markets survived after sub-prime mortgage crisis. There have been about 28 cycles of expansions and contraction, known as boom and bust cycles. The data shows that the boom cycle lasts for 38.7 months, while the bust cycle -17.5 months. The change has been quite small since the 2008 global financial crisis. Fears of recession appeared among analyzers, economists, and investors.

\section{Rising Unpredictability}

The way safe haven currencies and assets, especially the USD, reacted to the events of the Great Recession caused a fundamental change in the way experts comment the global economy. According to them, the reaction of safe havens does not always repeat history examples. Nowadays they are influenced by the specific features of the new epoch and are moving in unexpected ways.

According to an article from the Financial Times (2017), economists declared that all assumptions about safe haven currencies and assets are an act "fraught with risk". For example, they use the term "risk-off" periods when there is a flight to less risky assets such as bonds in the markets. From 2007 to 2016, the USD was the second most consistent safe haven. But the tendency was not the same for the last three years. It was falling rather than increasing during "risk-off" periods. In other words, all predictions of the experts may introduce risk in or risk off.
The unpredictability of the safe havens is shown in the Wall Street Journal report (March, 2018) with the strengthening of the USD and the JPY in tandem while the market stress was growing as expected. The gold, treasuries, the CHF depreciated, "confounding analysts and investors".

Gold is a safe haven for investors during crisis. Yet this is not necessarily the case in times of confidence in the fundamentals of the economy. At the same time gold is not a safe haven against any special asset class. Mainly it is a protection against systemic risk. That is an insurance against the current monetary system based on the fiat USD.

\section{Market tradition}

In every uncertainty of the US equity market as well as the decline of the USD, the investor may consider investing in safe haven currencies like the JPY or the CHF. The JPY is currently undervalued on a PPP basis making it a more attractive pick. (Williams, 2017). For investors around the world the JPY means safety so they try to take advantage of this. If we know that the JPY is going to rise, when the world economy falls into panic, then there is no problem buying it even if we are not sure what action other market players will take.

\section{The Bitcoin as Safe Haven}

The investors were pushed to look for a new safe haven as a result of the rising tension between the United States and China that pressed the markets and raised fears of economic recession the previous year. Bitcoin in particular has become more attractive to investors. It is not directly exposed to political forces provoking market turbulences. Its decentralized nature not dictated by a single government saves the cryptocurrencies from any intervention on the part of the central bank or by any political party policy. The isolated character helped bitcoin reach recent multi-month highs in the global equity trade. 


\section{Articles}

In other words, traders looked for refuge in the cryptocurrency because they cannot find refuge elsewhere.

By way of conclusion it should be assumed that unexpected asset price volatility is a constant market problem for investors. All types of safe haven assets, safe haven currencies in particular, are the best way for investors' protection against the systemic risks of the current monetary system.

\section{References}

Bank for International Settlement, Triennial Central Bank Survey - Foreign exchange turnover in April 2019; available at: https:// www.bis.org/statistics/rpfx19_fx.pdf. (last accessed 16 Nov 2020)

Caballero, R., E. Farhi, and Gourinchas, P. (2017) "The Safe Assets Shortage Conundrum", Journal of Economic Perspectives, 31(3): 29-46.

Caballero, R., E. Farhi, and Gourinchas, P. (2016). "Safe Asset Scarcity and Aggregate Demand", American Economic Review, 106(5): 513-18.

Caballero, R., J. Ricardo, and Simsek, A. (2013) "Fire Sales in a Model of Complexity", The Journal of Finance, 68(6): 2549-87.

Dang, Tri Vi, and Gorton, G. (2015). "Ignorance, Debt and Financial Crises", available at: http:// www.columbia.edu , Paper_Ignorance.pdf. (last accessed 16 Nov 2020)

Du, W., J. and Schreger, J. (2018): "The U.S. Treasury Premium", Journal of International Economics, 112(C):167-181.

Farhi, E., and M. Maggiori, (2016): A Model of the International Monetary System, NBER Working Paper No. 22295.

Financial Times, "Haven currencies are not always a safe bet", 2017, available at: https:// www.ft.com/content/32e5b37a-a747-11e7-
Safe Haven Currencies

93c5-648314d2c72c. (last accessed 16 Nov 2020)

Fratzscher, M., (2009). "What Explains Global Exchange Rate Movements during the Financial Crisis?", ECB Working Paper No.1060, June.

Gorton, G., (2017). "The History and Economics of Safe Assets. Annual", Review of Economics, Vol.9: 547-586, August 2017.

Gourinchas, P.O., and Jeanne, O. (2012): "Global Safe Assets", BIS Working Paper No. 399, Monetary and Economic Department, December, 2012.

Habib, M. M. and Stracca, L. (2012). "Getting beyond carry trade. What makes a safe haven currency?" Journal of International Economics, 87(1):50-64.

Habib, M., L. Stracca and Venditti, F. (2020). "The Fundamentals of Safe Assets", ECB Working Paper, No. 2355, January 2020.

He, Z., A. Krishnamurthy, and Milbradt, K. (2016). "What Makes US Government Bonds Safe Assets?", American Economic Review, 106(5):519-523.

Hui, C., H. Genberg and Chung, T. (2010) "Funding liquidity risk and deviations from interest rate parity during the financial crisis of 2007-2009", International Journal of Finance \& Economics, n./a. doi:10.1002/ijfe.427.

Mariathasan,J. (2018). "The Dollar: A safe haven emerges", IPE, available at: https:// www.ipe.com/the-dollar-a-safe-havenemerges/10023453.article (last accessed 16 Nov 2020)

Kerkhoff, M. (2016). "Why Is the Japanese Yen a Safe-Haven Currency?", Fiancial Sense website, 14 June 2016; available at: www. financialsense.com/contributors/matthewkerkhoff/why-japanese-yen-safe-havencurrency (last accessed 16 Nov 2020) 


\section{Articles}

Krishnamurthy, A., and Vissing-Jorgensen, A. (2012): "The Aggregate Demand for Treasury Debt", Journal of Political Economy, Vol. 120, 233-267.

Masujima, Y., (2016). "Yen Safe-haven Index Shows Heat Still on BOJ", Bloomberg, Intelligence INSIGHT, 28 September 2016.

Masujima, Y., (2019). What Determines A SafeHaven Currency? Bloomberg, RJETI Discussion Paper Series XX-E-00X, June, 2019.

McCauley, R.N. and McGuire, P. (2009), "Dollar Appreciation in 2008. Safe Haven, Carry Trades, Dollar Shortage and Overhedging", BIS Quarterly Review, December, 2009

Ronaldo, A. and Soderlind, P. (2007), Safe Haven Currencies, University of St.Gallen, Discussion Paper No. 2007-22.

Ronaldo, A. and P. Soderlind, (2009), "Safe Haven Currencies", Review of Finance, 14(3): 383-407.
Tabuchi, H., (2011). In Japan, a Tenuous Vow to Cut, Global Business, News Analysis, September 1, 2011.

The Wall Street Journal, "Safe Haven Assets are Moving Strangely: Why That Should Worry Investors,"; 30 march 2018, available at: https://www.wsj.com/articles/safe-havenassets-are-moving-strangely-why-thatshould-worry-investors-1522436950 (last accessed 16 Nov 2020)

Williams, S. M., (2017). The Yen: A Safe Haven Currency. available at: https://www. google.com/search?client=firefox-b- $d \& q=W$ illiams $\% 2 \mathrm{C}+$ Steven+M. $\% 2 \mathrm{C}+\mathrm{The}+\mathrm{Yen} \% 3$ $\mathrm{A}+\mathrm{A}+\mathrm{Safe}+$ Haven+Currency $\% 2 \mathrm{C}+$ Sep. $1 \%$ 2C+2017 (last accessed 16 Nov 2020)

For 28th straight year, Japan ranks No. 1 for overseas assets, May 25, 2019; available at: https://www.j-abc.com/blog/for-28th-straightyear-japan-ranks-no-1-for-overseas-assets. html (last accessed 16 Nov 2020) 